\title{
Review Article \\ The Current Situation of Wind Energy in Turkey
}

\author{
Raşit Ata \\ Department of Electrical \& Electronic Engineering, Celal Bayar University, 45140 Manisa, Turkey
}

Correspondence should be addressed to Raşit Ata; rasit.ata@cbu.edu.tr

Received 13 February 2013; Accepted 5 April 2013

Academic Editor: Mattheos Santamouris

Copyright (C) 2013 Raşit Ata. This is an open access article distributed under the Creative Commons Attribution License, which permits unrestricted use, distribution, and reproduction in any medium, provided the original work is properly cited.

\begin{abstract}
Wind energy applications and turbine installations at different scales have increased since the beginning of this century. As wind energy is an alternative clean energy source compared to the fossil fuels that pollute the atmosphere, systems that convert wind energy to electricity have developed rapidly. Turkey's domestic fossil fuel resources are extremely limited. In addition, Turkey's geographical location has several advantages for extensive use of wind power. In this context, renewable energy resources appear to be one of the most efficient and effective solutions for sustainable energy development and environmental pollution prevention in Turkey. Among the renewable sources, Turkey has very high wind energy potential. According to the Organization for Economic Cooperation and Development (OECD) Turkey theoretically has $166 \mathrm{TWh}$ a year of wind potential. However the installed wind power capacity is approximately $14 \%$ of total economical wind potential. In this study, Turkey's installed electric power capacity and electric energy production are investigated and also the current situation of wind energy in Turkey is examined. The wind data used in this study were taken from Turkish Wind Energy Association (TUREB) for the year 2012. This paper reviews the assessment of wind energy in Turkey as of the end of July 2012 including wind energy applications.
\end{abstract}

\section{Introduction}

During recent years according to global environmental pollutions, trends towards the sustainable energy and green power sources such as solar, wind, biomass, and geothermal energy were largely increased. It is now widely accepted that the renewable energy sources are very important for the future of the countries. Wind energy is one of the economic renewable sources and a valuable supplement to conventional energy sources. The wind technology was gradually improved since the early 1970s. By the end of the 1990s, wind energy has re-emerged as one of the most important renewable energy resources [1]. The cost of wind electricity production cost has been gradually decreasing with improving technology. At present, wind energy has been widely used to produce electricity in many countries in America, Asia, and especially Europe. For instance, while the world established wind power is $24,322 \mathrm{MW}$ in 2001 , it has increased to $237,016 \mathrm{MW}$ in the end of 2011 [2].

Our country, just as the majority of all world countries, faces some short and long term problems in energy procurement. Turkey should at first attempt to increase the amount of energy acquired from new and renewable energy sources to cover basic requirements of society and realize economic expansion, refrain as much as possible from local and global environmental problems caused by energy consumption and production, and especially reduce foreign-dependency in energy. This is valid for not only our country but also other countries of the world [3].

Especially in the last decade, many scientific studies were presented about the development of wind energy. A general review about wind energy development in Turkey is considered by Sahin [4]. Some authors have researched the developments in wind engineering and turbines, for example, Ackerman and Söder [5], Sahin [6], Thresher et al. [7], and Joselin Herbert et al. [8]. In [9-11] authors presented control techniques for composite wind turbine blades. Many authors have studied the status of wind energy, the wind energy potential of Turkey's different geographical regions [1233]. A general review about wind energy status, renewable energy potential, and development in Turkey is considered by researchers in [34-41]. In these studies, Turkey's installed wind power capacity and electric energy production are investigated and also Turkey current wind energy status is examined by researchers. Ozgener and Hepbasli [42] 


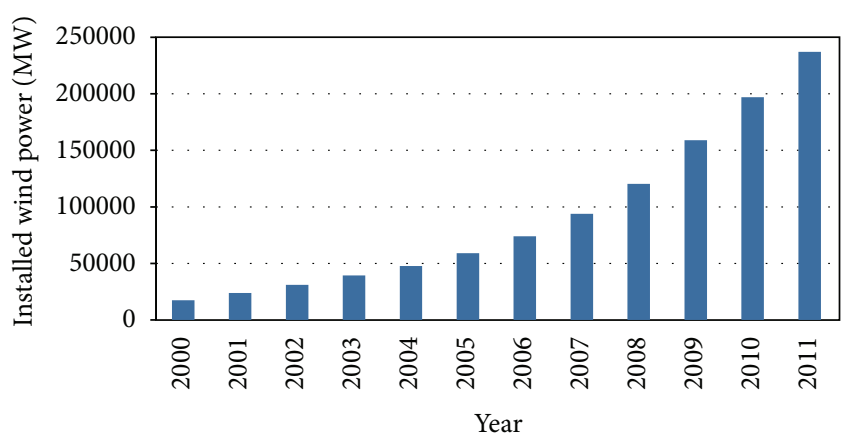

FIGURE 1: Installed wind power capacity of the world.

presented future directions of wind energy applications in Turkey. Many authors have researched the status, potential, utilization, environmental pollution, and future perspectives of renewable energy sourches, for example, Evrendilek and Ertekin [43], Ocak et al. [44], Yüksel [45], Oğulata [46], Keleş and Bilgen [47], Çapik et al. [48], Yuksel and Kaygusuz [49], Volkan and Ediger [50], Kaya [51], Kaygusuz and Sari [52], and Akpinar et al. [53]. In addition, Kenisarin et al. [54] has discussed wind power engineering in the world and its development in Turkey.

In this paper, wind energy and its importance are discussed firstly, and then the current status and development of Turkey's wind power plants are investigated in detail.

\section{Situation of Wind Energy in the World}

Wind energy is the most advanced and widespread renewable energy source being the most convenient in commercial terms. Being a clean energy source, wind energy is environment friendly having no possibility of extinction as long as the sun exists. It is an ever growing energy source despite being continuous and despite the fact that it is not exactly known whether available amount will be at hand when required. For instance, while the world established wind power is $24,322 \mathrm{MW}$ in 2001, it has increased to $215,000 \mathrm{MW}$ in June 2011 [2]. Figure 1 shows installed wind power capacity in the world between 2000 and 1st half 2011 [2, 55]. There is an increasing trend in installed wind energy and average increasing rate is $25 \%$ over this period. It is estimated that installed wind power will be reached in $24,500 \mathrm{MW}$ by the end of 2011 [2].

Approximately $43.7 \%$ of the installed wind capacity of the world is in Europe, 22.5\% in North America, and 31.1\% in Asia. However, China has the highest installed wind capacity with $44,733 \mathrm{MW}$ which is equal to $52 \%$ of Europe's and $22.7 \%$ of world installed capacity. The top ten wind energy markets are shown in Figure 2 between 2009 and 2010 [56].

As it is seen from Figure 2 China shows the highest development in installed wind energy capacity with $73 \%$ between 2009 and 2010. USA has also high development with $14.2 \%$. The increasing rate of installed wind capacity in this term for Germany, Spain, and India is 5.5, 7.9, 10.6\%, respectively. Although the established power of wind energy has recently increased in the countries in the Asian continent,

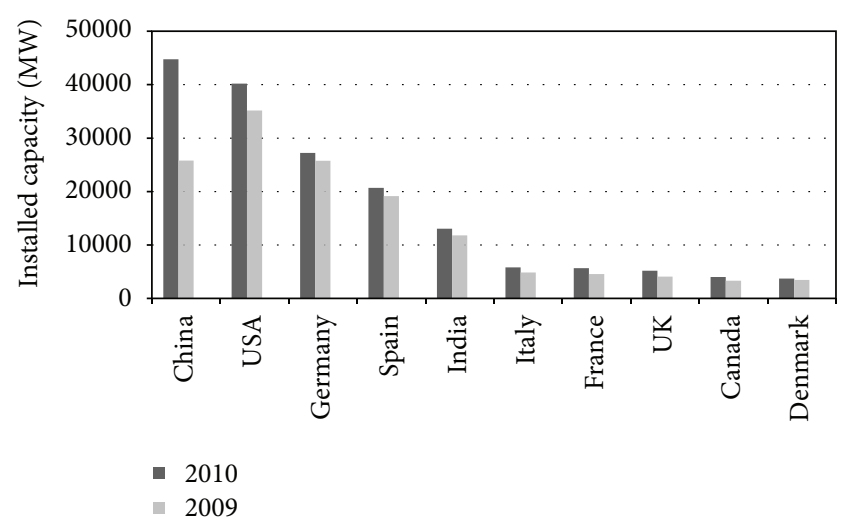

Figure 2: Top ten countries in terms of total installed wind power capacity in the world.

$43.7 \%$ of the established power of world wind energy is in the European continent, according to 2010 data.

According to 2010 data of Balkan countries being under the influence of almost similar wind systems to Turkey, our bordering neighbor Greece has $1208 \mathrm{MW}$ of wind energy established power, while Bulgaria has above $375 \mathrm{MW}$ of established wind power. Based on a comparison with our neighbors, the significance of the potential of our country is blatant, only when we consider the great surface area of our country.

\section{Turkey's Electrical Energy Status}

The main purpose of energy policy in Turkey is to supply the sufficient energy to the utilization taking environmental and economic aspects into account by supporting the economical growing and social development [57]. The trend of growing has been calculated to be continuing in future. Turkey's total installed power capacity obtained from hydraulic, thermal (natural gas, coal, lignite, fuel-oil, LPG, etc.), and wind sources is $49,524 \mathrm{MW}$ at the end of the 2010, an increase of $10.6 \%$ over 2009 . From 2000 to 2010 total capacity increased by $74.6 \%$. This was one of the largest increases in IEA member countries, reflecting a significant build-up in CCGTs but also coal and hydro capacity [58]. Together, natural gas, hydropower, oil, and coal plants account for $97 \%$. Distribution of the installed power capacity of Turkey according to the sources is given in Figure 3 [59]. As it is seen from Figure 3, the rate of thermal source power plants is very high and approximately $75 \%$ of these are natural gas plants.

The total gross electrical energy production in 2010 was 211,207.7 GWh and changes in the production rate depended on the economic situations and technological developments. Average increasing rate was approximately $8.4 \%$ in this term [59]. Turkey's electrical energy production from 2005 to 2010 is shown in Figure 4 [59]. Although electrical energy production has increased gradually, there was a decrease in electrical energy production in 2009. Electricity production was realized as $194,812 \mathrm{GWh}$ with a decrease about $2 \%$ in 2009 when compared to the values of 2008 , that is, $198,418 \mathrm{GWh}$. 


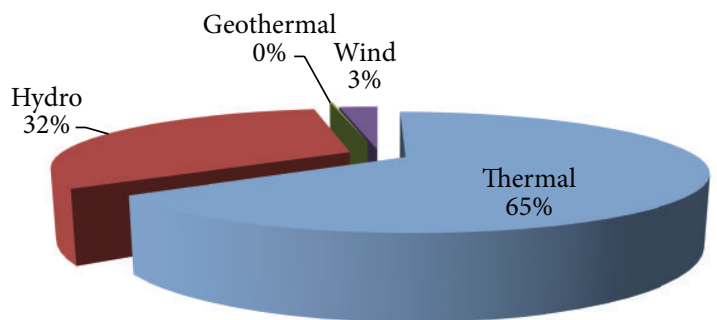

FIGURE 3: Distribution of installed power capacity of Turkey.

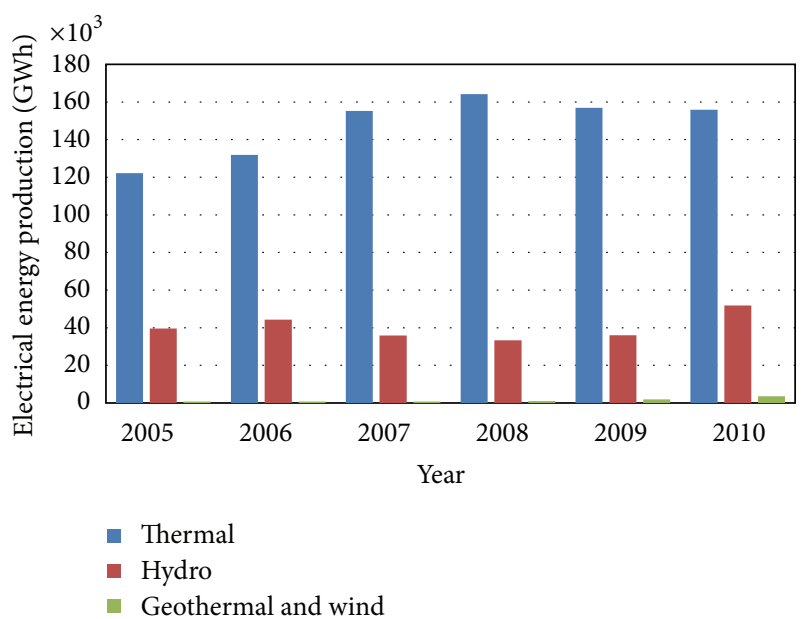

FIGURE 4: Turkey's gross electrical energy production for the years 2005-2010.

Annual developments of the gross electrical energy production according to sources between 2005 and 2010 are given in Table 1 [59]. As it is seen from Table 1, 73\% of the electrical energy is supplied from thermal sources. It can be seen that the proportion of natural gas in the electrical energy production increased approximately $33.6 \%$ in this term. In electrical energy production, consumption of natural gas reached $46 \%$ in 2010 whereas it was $37 \%$ in 2000 [39]. However, the natural gas share of the world in production of electrical energy is $21.4 \%$ [60]. Since Turkey imports almost all required natural gas, this high rate usage in producing electricity than the world is an important point to be examined economically [39]. On the other hand, electrical energy production from the wind has grown rapidly in recent years.

\section{The Current Situation of Wind Energy in Turkey and Its Future}

A wind atlas of Turkey published by the Turkish Energy Market Regulatory Agency (EPDK) in May 2002 indicates that the regions with the highest potential for wind speeds at height of $50 \mathrm{~m}$ are the Aegean, Marmara, and Eastern Mediterranean regions of Turkey, as well as some mountainous regions of central Anatolia [61]. Figure 5 shows scattering of average wind speed in $50 \mathrm{~m}$ high in Turkey [3]. In addition to this,

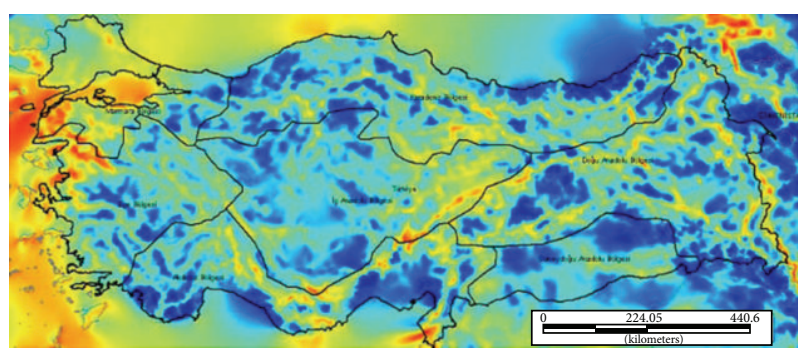

Wind speed $(\mathrm{m} / \mathrm{s})$

$\begin{array}{lll}\square 10 & \square 7.5 & \square 5 \\ \square 9.5 & \square 7 & \square 4.5 \\ \square 9 & \square 6.5 & \square 4 \\ \square 8.5 & \square 6 & \square 3.5 \\ \square 8 & \square 5.5 & \square 3\end{array}$

FIGURE 5: Scattering of average wind speed at $50 \mathrm{~m}$ high in Turkey.

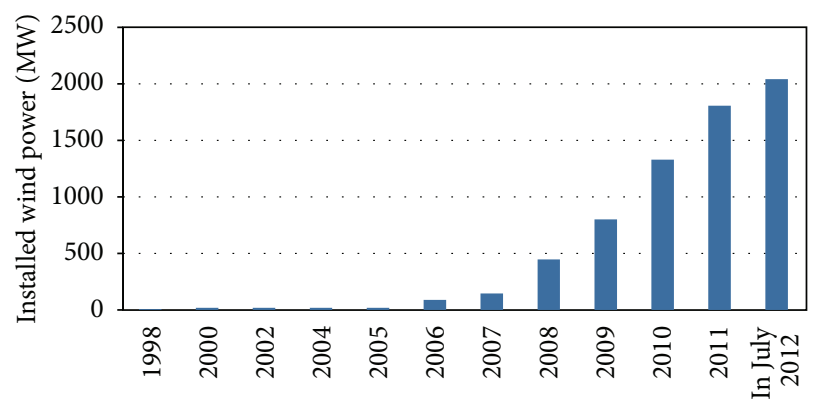

Year

FIGURE 6: Installed wind power capacity in Turkey.

meteorological data by the USA space studies have shown that Turkey has high wind capacity [39].

Power intensity in $50 \mathrm{~m}$ of elevation above ground, which is significant to establish turbines, in places with $4-5 \mathrm{~m} / \mathrm{s}$ of average annual wind speed at $50 \mathrm{~m}$ of elevation above ground mostly exceed annual average of $500 \mathrm{w} / \mathrm{m}^{2}$. Estimated figures resulting from the researcher conducted in the field, technical wind energy potential of Turkey, established power, and average efficiencies are available in Table 2 [3]. In this table, the land of Turkey has been classified by means of wind energy resource degree. It can be seen from this table that approximately $37 \%$ of the land of Turkey has capacity above medium.

First small-scale application to generate electrical energy in Turkey was started with a plant that has $55 \mathrm{~kW}$ installed power in Izmir-Çeşme in the Aegean region in 1986. The first power plant in large-scale was also installed in 1998, Çeşme-Germiyan with 1.74 MW capacity. In 1998, the ARES wind farm was built in Çeşme-Alaçatı and included $12 \times$ $600 \mathrm{~kW}$ wind turbines. The biggest wind energy power plant in Turkey has $140.1 \mathrm{MW}$ capacity constructed in ManisaSoma in 2012. Current wind power plants under operation in Turkey are listed in Table 3 [62]. Installed wind power capacity for electrical production is shown in Figure 6 [62]. 
TABLE 1: Distribution of resources of the Turkey's gross electrical energy production (GWh).

\begin{tabular}{|c|c|c|c|c|c|c|}
\hline Resources & 2005 & 2006 & 2007 & 2008 & 2009 & 2010 \\
\hline Hard coal + Imp. coal & 13246.2 & 14216.6 & 15236.2 & 15857.5 & 16595.6 & 19104.3 \\
\hline Lignite & 29946.3 & 32432.9 & 38294.7 & 41858.1 & 39089.5 & 35942.1 \\
\hline Fuel-oil & 5120.7 & 4232.4 & 6469.6 & 7208.6 & 4439.8 & 2143.8 \\
\hline Diesel & 2.5 & 57.7 & 13.3 & 266.3 & 345.3 & 4.3 \\
\hline Natural gas & 73444.9 & 80691.2 & 95024.8 & 98685.3 & 96094.7 & 98143.7 \\
\hline Renew. and wastes & 122.4 & 154.0 & 213.7 & 219.9 & 340.1 & 457.5 \\
\hline Others & 359.3 & 50.3 & 43.9 & 43.6 & 18.0 & 31.9 \\
\hline Total thermal & 122242.3 & 131835.1 & 155196.2 & 164139.3 & 156923.4 & 155827.6 \\
\hline Hydro & 39560.5 & 44244.2 & 35850.8 & 33269.8 & 35958.4 & 51795.5 \\
\hline Geothermal + wind & 153.4 & 220.5 & 511.1 & 1008.9 & 1931.1 & 3584.6 \\
\hline Total & 161956.2 & 176299.8 & 191558.1 & 198418.0 & 194812.9 & 211207.7 \\
\hline
\end{tabular}

TABLE 2: Areal distribution of wind speed, power and potential energy amount in Turkey.

\begin{tabular}{lcccccc}
\hline $\begin{array}{l}\text { Wind source } \\
\text { degree }\end{array}$ & Wind class & $\begin{array}{c}\text { Wind power at } 50 \mathrm{~m} . \\
\left(\mathrm{W} / \mathrm{m}^{2}\right)\end{array}$ & $\begin{array}{c}\text { Wind speed at } 50 \mathrm{~m} . \\
(\mathrm{m} / \mathrm{s})\end{array}$ & $\begin{array}{c}\text { Overall area } \\
\left(\mathrm{km}^{2}\right)\end{array}$ & $\begin{array}{c}\text { Windy land } \\
(\%)\end{array}$ & $\begin{array}{c}\text { Potential capacity } \\
(\mathrm{MW})\end{array}$ \\
\hline Medium & 3 & $300-400$ & $6.8-7.5$ & 16781.39 & 2.27 & 83906.96 \\
Good & 4 & $400-500$ & $7.5-8.1$ & 5851.87 & 0.79 & 29259.36 \\
Perfect & 5 & $500-600$ & $8.1-8.6$ & 2598.86 & 0.35 & 12994.32 \\
Perfect & 6 & $600-800$ & $8.6-9.5$ & 1079.98 & 0.15 & 5399.92 \\
Perfect & 7 & $>800$ & $>9.5$ & 39.17 & 0.01 & 195.84 \\
\hline Total & & & & & 3.57 & 131756.40 \\
\hline
\end{tabular}

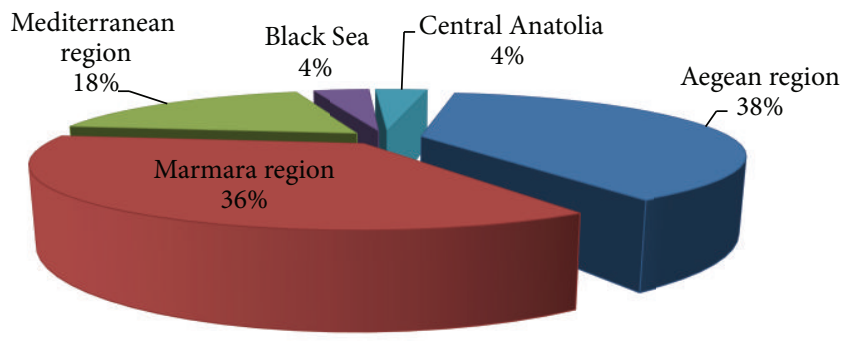

FIGURE 7: Distribution of wind energy power stations according to the regions in Turkey.

Having a look at Table 3, the existing wind power stations are active only in the five of the seven geographical regions of the country, being Aegean, Marmara, Mediterranean, Black Sea, and Central Anatolia regions. While Aegean ranks first with 786.2 MW of established power, Marmara region with $730.65 \mathrm{MW}$ of established power ranks second to be followed by the Mediterranean region with $372.5 \mathrm{MW}$ of established wind power energy station capacity. Distribution of wind energy power stations according to the regions in Turkey is shown in Figure 7.

Considering the distribution of installed power according to provinces, Balıkesir ranks first, as is seen in Table 4, having almost $20 \%$ of the overall capacity. Manisa ranks second with $17 \%$ of share, İzmir, again a city from the Aegean region, ranks third with $16 \%$ of the total capacity, then the other provinces listed. In the near future, the number of provinces with active wind power stations is expected to be further augmented.

In 2010, $528 \mathrm{MW}$ of new wind energy capacity was added in Turkey, bringing the total up to $1329 \mathrm{MW}$. This represents a year-on-year growth rate of $66 \%$. According to TEIAS (the state-owned transmission company and system operator) it is projected that up to $415.8 \mathrm{MW}$ of wind projects might be added in 2011 [61].

Installed wind capacity is expected to grow between 500$1,000 \mathrm{MW}$ per year reaching more than $5 \mathrm{GW}$ by 2015. Turkey hopes to install up to $20 \mathrm{GW}$ by 2023 , helping the country to source $30 \%$ of its electricity generation from renewable sources by that date. In order to reach this target, however, the transmission infrastructure will require substantial upgrades to allow such large scale developments to be connected to the power grid. This issue will need to be addressed in the near future [61].

The predicted wind power development capacity in Turkey can be seen in Table 5 [54]. Two different assumptions have been made in this table. According to both predictions, the power obtained from wind will increase and exceed 10,000 MWs by 2030 .

The new renewable energy law introduced fairly attractive incentives for wind power plants in Turkey. In early 2007, the Turkish government updated the renewable energy law that guarantees wind generators with 10 year agreements involving a fixed tariff between 50/MWh and 55/MWh. Although somewhat lower than tariffs in other developing markets, for example, 73/MWh in Brazil or the 66/MWh set in Portugal, the tariff, coupled with the high wind potential, 
TABLE 3: Wind power plants under operation in Turkey (July 2012).

\begin{tabular}{|c|c|c|c|c|c|}
\hline Name of windfarm & Installed capacity (MW) & Turbine power & Turbine brand & Location & Production date \\
\hline Çeşme & 1.50 & $0.5 \mathrm{MW}$ & Enercon & İzmir-Çeşme & 1998 \\
\hline Ares & 7.20 & $0.6 \mathrm{MW}$ & Vestas & İzmir-Çeşme & 1998 \\
\hline Bozcaada & 10.20 & $0.6 \mathrm{MW}$ & Enercon & Çanakkale-Bozcaada & 2000 \\
\hline Intepe & 30.40 & $0.8 \mathrm{MW}$ & Enercon & Çanakkale-İntepe & 2007 \\
\hline Karakurt & 10.80 & $1.8 \mathrm{MW}$ & Vestas & Manisa-Akhisar & 2007 \\
\hline Burgaz & 14.90 & $0.8 \mathrm{MW}+0.9 \mathrm{MW}$ & Enercon & Çanakkale-Gelibolu & 2007 \\
\hline Sayalar & 34.20 & $0.9 \mathrm{MW}$ & Enercon & Manisa-Sayalar & 2008 \\
\hline Çatalca & 60.00 & $3 \mathrm{MW}$ & Vestas & İstanbul-Çatalca & 2008 \\
\hline Yuntdağ & 57.50 & $2.5 \mathrm{MW}$ & Nordex & İzmir-Aliağa & 2008 \\
\hline Kemerburgaz & 24.00 & $2 \mathrm{MW}$ & Enercon & İstanbul-Gaziosmanpaşa & 2008 \\
\hline Mare manastır & 39.20 & $0.9 \mathrm{MW}+0.8 \mathrm{MW}$ & Enercon & İzmir-Çeşme & $2006 / 2007$ \\
\hline Sunjut & 1.20 & $0.6 \mathrm{MW}$ & Enercon & İstanbul-Hadımköy & 2003 \\
\hline Teperes & 0.85 & $0.85 \mathrm{MW}$ & Vestas & İstanbul-Silivri & 2006 \\
\hline Bandirma & 35.00 & $1.5 \mathrm{MW}$ & GE + Nordex & Balıkesir-Bandırma & 2006 \\
\hline Şamlı & 114.00 & $3 \mathrm{MW}$ & Vestas & Balıkesir-Şamlı & 2008 \\
\hline Datça & 29.60 & $0.8 \mathrm{MW}+0.9 \mathrm{MW}$ & Enercon & Muğla-Datça & 2008 \\
\hline Sebenoba & 30.00 & $2 \mathrm{MW}$ & Vestas & Hatay-Samandağ & 2008 \\
\hline Akbuk & 31.50 & $2.1 \mathrm{MW}$ & Suzlon & Aydın-Didim & 2009 \\
\hline Çamseki & 20.80 & $2 \mathrm{MW}+0.8 \mathrm{MW}$ & Enercon & Çanakkale-Ezine & 2009 \\
\hline Keltepe & 20.70 & $0.9 \mathrm{MW}$ & Enercon & Balıkesir-Susurluk & 2009 \\
\hline Gökçedağ & 135.00 & $2.5 \mathrm{MW}$ & GE & Osmaniye-Bahçe & $2009 / 2010$ \\
\hline Düzova & 30.00 & $2.5 \mathrm{MW}$ & GE & İzmir-Bergama & $2009 / 2010$ \\
\hline Mazi-3 & 30.00 & $2.5 \mathrm{MW}$ & Nordex & İzmir-Çeşme & $2009 / 2010$ \\
\hline Ayyıldız & 15.00 & $3 \mathrm{MW}$ & Vestas & Balıkesir-Bandırma & 2009 \\
\hline Bandirma & 60.00 & $3 \mathrm{MW}$ & Vestas & Balıkesir-Bandırma & $2009 / 2010$ \\
\hline Soma & 140.10 & $2 \mathrm{MW}+0.9 \mathrm{MW}$ & Enercon & Manisa-Soma & $2011 / 2012$ \\
\hline Belen & 36.00 & $3 \mathrm{MW}$ & Vestas & Hatay-Belen & $2009 / 2010$ \\
\hline Sarıkaya & 28.80 & $2 \mathrm{MW}+0.8 \mathrm{MW}$ & Enercon & Tekirdağ-Şarköy & 2009 \\
\hline Kocadağ-2 & 17.50 & $2.5 \mathrm{MW}$ & Nordex & İzmir-Urla & 2010 \\
\hline Bandirma-3 & 25.00 & $2.5 \mathrm{MW}$ & Nordex & Balıkesir-Bandırma & 2010 \\
\hline Mersin & 33.00 & $3 \mathrm{MW}$ & Vestas & Mersin-Mut & 2010 \\
\hline Boreas-1 & 15.00 & $2.5 \mathrm{MW}$ & Nordex & Edirne-Enez & 2010 \\
\hline Aliağa & 90.00 & $2.5 \mathrm{MW}$ & Nordex & İzmir-Aliağa & 2010 \\
\hline Şenbuk & 15.00 & $3 \mathrm{MW}$ & Vestas & Hatay-Belen & 2010 \\
\hline Ziyaret & 57.50 & $2.5 \mathrm{MW}$ & GE & Hatay-Samandağ & $2010 / 2011$ \\
\hline Soma & 90.00 & $2.5 \mathrm{MW}$ & Nordex & Manisa-Soma & 2010 \\
\hline Kuyucak & 25.60 & $2 \mathrm{MW}+0.8 \mathrm{MW}$ & Enercon & Manisa-Kırkağaç & 2010 \\
\hline Sares & 22.50 & $2.5 \mathrm{MW}$ & GE & Çanakkale-Ezine & $2010 / 2011$ \\
\hline Turguttepe & 24.00 & $2 \mathrm{MW}$ & Vestas & Aydın-Çine & 2010 \\
\hline Çataltepe res & 16.00 & $2 \mathrm{MW}$ & Enercon & Balıkesir & 2010 \\
\hline Çanakkale & 29.90 & $2.3 \mathrm{MW}$ & Siemens & Çanakkale-Ezine & 2011 \\
\hline Susurluk & 45.00 & $2.5 \mathrm{MW}$ & Nordex & Balıkesir-Susurluk & 2011 \\
\hline Seyitali res & 30.00 & $2 \mathrm{MW}$ & Enercon & İzmir & 2011 \\
\hline Söke-Çatalbük & 30.00 & $2 \mathrm{MW}$ & Gamesa & Aydın & 2012 \\
\hline Aksu & 72.00 & $2 \mathrm{MW}$ & Vestas & Kayseri & 2012 \\
\hline Amasya & 40.00 & $2.5 \mathrm{MW}$ & Nordex & Amasya & 2012 \\
\hline Metristepe & 40.00 & $2.5 \mathrm{MW}$ & Nordex & Bilecik & 2012 \\
\hline Dağpazarı & 39.00 & $3 \mathrm{MW}$ & Siemems & Mersin & 2012 \\
\hline Şenköy & 27.00 & $3 \mathrm{MW}$ & Alstom W. & Hatay & 2012 \\
\hline Şahres & 93.00 & $3 \mathrm{MW}$ & Vestas & Balıkesir & 2011 \\
\hline
\end{tabular}


TABLE 3: Continued.

\begin{tabular}{|c|c|c|c|c|c|}
\hline Name of windfarm & Installed capacity (MW) & Turbine power & Turbine brand & Location & Production date \\
\hline Ayres & 5.00 & $1.8 \mathrm{MW}$ & Vestas & Çanakkale & 2011 \\
\hline Akres & 45.00 & $2.5 \mathrm{MW}$ & Nordex & Manisa & 2011 \\
\hline Karadağ & 10.00 & $2.5 \mathrm{MW}$ & GE & İzmir & 2012 \\
\hline Bozyaka & 12.50 & $2.5 \mathrm{MW}$ & Nordex & İzmir & 2011 \\
\hline Killik & 40.00 & $2.5 \mathrm{MW}$ & Nordex & Tokat & 2012 \\
\hline Saray & 4.00 & $2 \mathrm{MW}$ & Enercon & İstanbul & 2012 \\
\hline Total & 2041.35 & & & & \\
\hline
\end{tabular}

TABLE 4: Distribution of installed capacity according to Provinces of Turkey.

\begin{tabular}{lc}
\hline Provinces & Installed capacity (MW) \\
\hline Balıkesir & 423.10 \\
Manisa & 345.70 \\
İzmir & 325.40 \\
Hatay & 165.50 \\
Osmaniye & 135.00 \\
Çanakkale & 133.70 \\
İstanbul & 90.05 \\
Aydın & 85.50 \\
Mersin & 72.00 \\
Kayseri & 72.00 \\
Tokat & 40.00 \\
Amasya & 40.00 \\
Bilecik & 40.00 \\
Muğla & 29.60 \\
Tekirdă̆ & 28.80 \\
Edirne & 15.00 \\
\hline
\end{tabular}

TABle 5: Prediction of wind power development capacity in Turkey.

\begin{tabular}{lcc}
\hline Years & Wind energy, $\mathrm{MW}^{*}[35]$ & Wind energy, $\mathrm{MW}^{*}[54]$ \\
\hline $2000^{* *}$ & 19 & 19 \\
$2010^{* *}$ & 1329 & 1329 \\
2015 & 5142 & 7230 \\
2020 & 7849 & 10620 \\
2025 & 9733 & 13160 \\
2030 & 11200 & 15885 \\
\hline
\end{tabular}

${ }^{*}$ Calculation of the authors assuming a wind turbine utilization factor. ${ }^{* *}$ Statistical data.

provides good market prospects. The law also guarantees reduced costs for land access, generation, and licenses, as well as no VAT or custom taxes for wind equipment [4]. It is seen that this law has encouraged many investors for making investments given below regarding renewable energies in Turkey and especially wind energy.

\section{Wind Energy Economics}

The economics of wind power plants is influenced by a number of factors. These include the quality of the wind
TABLE 6: Electricity generation costs by fuel type (cent/kWh).

\begin{tabular}{lcc}
\hline Power source & Minimum & Maximum \\
\hline Large hydro & 3.0 & 13.0 \\
Small hydro & 4.0 & 14.0 \\
Municipal solid wastes & 4.2 & 6.3 \\
Bio mass & 4.2 & 7.9 \\
Natural gas & 4.3 & 5.4 \\
Coal & 4.5 & 7.0 \\
Agricultural residues & 4.5 & 9.8 \\
Wind & 4.7 & 7.2 \\
Geothermal & 4.7 & 7.8 \\
Hydraulic & 5.2 & 18.9 \\
Nuclear & 5.3 & 9.3 \\
Solar thermal hybrid & 6.0 & 7.8 \\
Wave/tidal & 6.7 & 17.2 \\
Energy crops & 10.0 & 20.0 \\
Solar PV & 28.7 & 31.0 \\
\hline
\end{tabular}

TABLE 7: Cost structure of a typical $2 \mathrm{MW}$ wind turbine installed in Europe $(€ 2006)$.

\begin{tabular}{lcc}
\hline & $\begin{array}{c}\text { Investment } \\
(€ 1,000 / \mathrm{MW})\end{array}$ & $\begin{array}{c}\text { Share of total cost } \\
\%\end{array}$ \\
\hline Turbine (ex works) & 928 & 75.6 \\
Grid connection & 109 & 8.9 \\
Foundation & 80 & 6.5 \\
Land rent & 48 & 3.9 \\
Electric installation & 18 & 1.5 \\
Consultancy & 15 & 1.2 \\
\hline
\end{tabular}

resource, technology efficiency and reliability, the availability of long-term power contracts, and the ability to forecast at least several hours ahead. By far the most significant factors that contribute to wind energy value are related to the wind resource and the characteristics of the grid and the evolving market rules. As additional wind capacity is developed, these variables will be quantified more precisely. A cost comparison between wind energy and other energy production methods was shown in Table 6 [40]. It can be seen that wind energy is as economically usable as other common energy sources.

Approximately $75 \%$ of the total cost of energy for a wind turbine is related to upfront costs such as the cost of the turbine, foundation, electrical equipment, and grid-connection. 
Obviously, fluctuating fuel costs have no impact on power generation costs. Thus a wind turbine is capital-intensive compared to conventional fossil fuel fired technologies such as a natural gas power plant, where as much as $40-70 \%$ of costs are related to fuel and operation and maintenance. Table 7 gives the price structure of a typical $2 \mathrm{MW}$ wind turbine [63].

\section{Conclusions}

Under global climate change conditions, all countries have trended towards renewable energy sources to reduce carbon dioxide emissions into the atmosphere. Wind energy is the most suitable energy source among renewable sources because wind energy has great potential throughout the world, including Turkey, and it is sustainable and does not pollute the environment. So, it has become crucial for electricity production. In general, potential wind energy areas in Turkey lie in northern and the north-western parts, at locations along the Aegean Sea and Marmara Sea coast. Aegean, Marmara, East-Mediterranean, and South East Anatolia regions of Turkey are generally seen as promising of higher wind power potential compared to other part of Turkey. In Turkey the available wind power was $801 \mathrm{MW}$ by the end of the year 2009. This capacity reached $1329 \mathrm{MW}$ at the end of 2010. This capacity became $2041.35 \mathrm{MW}$ at the end of July 2012. The installed wind capacity of Turkey is approximately $14 \%$ of Turkey's total economical wind potential. However this rate will be increased after installing the licensed projects.

Turkey is facing serious challenges in satisfying its growing energy demand. To fuel a rapidly growing economy, the country's electricity consumption is increasing by an average of 8-9\% every year, and significant investments are needed in generation, transmission, and distribution facilities to balance the power system's supply and demand. Finally, Turkey is an energy-importing country. In order to be less dependent on other countries, Turkey needs to use its sustainable sources. From this point of view, wind power is a very attractive choice, since it is economical, sustainable, environment friendly, and a familiar energy source in Turkey.

\section{References}

[1] T. Burton, D. Sharpe, N. Jenkins, and E. Bossanyi, Wind Energy Handbook, John Wiley \& Sons, Chichester, UK, 2001.

[2] The World Wind Energy Association, Annual report, 2011, http://www.wwindea.org/.

[3] I. Akova, "Development potential of wind energy in Turkey," Echos Géographiques de Turquie, vol. 16, 2011.

[4] A. D. Sahin, "A review of research and development of wind energy in Turkey," Clean Soil Air Water, vol. 36, no. 9, pp. 734$742,2008$.

[5] T. Ackerman and L. Söder, "Wind energy technology and current status: a review," Renewable \& Sustainable Energy Reviews, vol. 4, pp. 315-374, 2000.

[6] A. D. Sahin, "Progress and recent trends in wind energy," Progress in Energy and Combustion Science, vol. 30, pp. 501-543, 2004.
[7] R. Thresher, M. Robinson, and P. Veers, "Wind energy technology: current status and R\&D future," in Proceedings of the Physics of Sustainable Energy Conference, University of California at Berkeley, 2008.

[8] G. M. Joselin Herbert, S. Iniyan, E. Sreevalsan, and S. Rajapandian, "A review of wind energy technologies," Renewable \& Sustainable Energy Reviews, vol. 11, no. 6, pp. 1117-1145, 2007.

[9] U. K. Galappaththi, A. K. M. De Silva, M. MacDonald, and O. R. Adewale, "Review of inspection and quality control techniques for composite wind turbine blades," Insight: Non-Destructive Testing and Condition Monitoring, vol. 54, pp. 82-85, 2012.

[10] Z. Qi and E. Lin, "Integrated power control for small wind power system," Journal of Power Sources, vol. 217, pp. 322-328, 2012.

[11] J. Yang, C. Peng, J. Xiao, J. Zeng, and Y. Yuan, "Application of videometric technique to deformation measurement for largescale composite wind turbine blade," Applied Energy, vol. 98, pp. 292-300, 2012.

[12] A. Öztopal, A. D. Sahin, Z. Sen, and N. Akgün, "On the regional wind energy potential of Turkey," Energy, vol. 25, pp. 189-200, 2000.

[13] H. Balat, "Wind energy potential in Turkey," Energy, vol. 23, pp. 51-56, 2005.

[14] R. T. Ogulata, "Energy sector and wind energy potential in Turkey," Renewable \& Sustainable Energy Reviews, vol. 7, pp. 469-484, 2003.

[15] R. K. Köse, "An evaluation of wind energy potential as a power generation source in Kütahya Turkey," Energy Conversion and Management, vol. 45, pp. 1631-1641, 2004.

[16] M. G. Gökçek, A. Bayülken, and S. Bekdemir, "Investigation of wind characteristics and wind energy potential in Kirklareli Turkey," Renewable Energy, vol. 32, pp. 1739-1752, 2007.

[17] M. Durak and Z. Şen, "Wind power potential in Turkey and Akhisar case study," Renewable Energy, vol. 25, no. 3, pp. 463472, 2002.

[18] E. K. Akpinar and S. Akpinar, "Determination of the wind energy potential for Maden-Elazig, Turkey," Energy Conversion and Management, vol. 45, no. 18-19, pp. 2901-2914, 2004.

[19] R. Köse, M. Arif Ozgur, O. Erbas, and A. Tugcu, "The analysis of wind data and wind energy potential in Kutahya, Turkey," Renewable \& Sustainable Energy Reviews, vol. 8, no. 3, pp. 277288, 2004.

[20] M. Bilgili, B. Sahin, and A. Kahraman, "Wind energy potential in Antakya and Iskenderun regions, Turkey," Renewable Energy, vol. 29, pp. 1733-1745, 2004.

[21] N. Eskin, H. Artar, and S. Tolun, "Wind energy potential of Gökçeada Island in Turkey," Renewable \& Sustainable Energy Reviews, vol. 12, pp. 839-851, 2008.

[22] A. Ucar and F. Balo, "Evaluation of wind energy potential and electricity generation at six locations in Turkey," Applied Energy, vol. 86, no. 10, pp. 1864-1872, 2009.

[23] Y. Oner, S. Ozcira, and N. Bekiroglu, "Prediction wind energy potential using by wind data analysis in bababurnu-Turkey," in Proceedings of the International Conference on Clean Electrical Power (ICCEP '09), pp. 232-235, June 2009.

[24] B. Sahin and M. Bilgili, "Wind characteristics and energy potential in Belen-Hatay, Turkey," International Journal of Green Energy, vol. 6, no. 2, pp. 157-172, 2009.

[25] B. Sahin, M. Bilgili, and H. Akilli, "The wind power potential of the eastern Mediterranean region of Turkey," Journal of Wind Engineering and Industrial Aerodynamics, vol. 93, no. 2, pp. 171183, 2005. 
[26] I. T. Togrul and C. Ertekin, "A statistical investigation on the wind energy potential of Turkey's geographical regions," Energy Sources Part A, vol. 33, no. 15, pp. 1399-1421, 2011.

[27] M. Bilgili and E. Simsek, "Wind energy potential and turbine installations in Turkey," Energy Sources Part B, vol. 7, pp. 140151, 2012.

[28] E. Camadan, "An assessment on the current status and future of wind energy in Turkish electricity industry," Renewable \& Sustainable Energy Reviews, vol. 15, pp. 4994-5002, 2011.

[29] C. Ilkılıç, "Wind energy and assessment of wind energy potential in Turkey," Renewable \& Sustainable Energy Reviews, vol. 16, pp. 1165-1173, 2012.

[30] C. Ilkılıç and I. Türkbay, "Determination and utilization of wind energy potential for Turkey," Renewable \& Sustainable Energy Reviews, vol. 14, pp. 2202-2207, 2010.

[31] A. A. Coskun and Y. O. Türker, "Wind energy and Turkey," Environmental Monitoring and Assessment, vol. 184, pp. 12651273, 2012.

[32] M. S. Celiktas and G. Kocar, "Foresight analysis of wind power in Turkey," International Journal of Energy Research, vol. 36, pp. 737-748, 2012.

[33] A. N. Celik, "Review of Turkey's current energy status: a case study for wind energy potential of Canakkale Province," Renewable \& Sustainable Energy Reviews, vol. 15, pp. 2743-2749, 2011.

[34] A. Hepbasli and O. Ozgener, "A review on the development of wind energy in Turkey," Renewable \& Sustainable Energy Reviews, vol. 8, no. 3, pp. 257-276, 2004.

[35] H. Aras, "Wind energy status and its assessment in Turkey," Renewable Energy, vol. 28, pp. 2213-2220, 2003.

[36] M. Bilgili, "A global review of wind power installations and their development in Turkey," Clean Soil Air Water, vol. 37, no. 3, pp. 195-202, 2009.

[37] M. Gökçek, "Developing Wind Energy in Turkey," 2012, http://www.intechopen.com/.

[38] K. Kaygusuz, "Wind energy status in renewable electrical energy production in Turkey," Renewable \& Sustainable Energy Reviews, vol. 14, pp. 2104-2112, 2010.

[39] O. Guler, "Wind energy status in electrical energy production of Turkey," Renewable \& Sustainable Energy Reviews, vol. 13, pp. 473-478, 2009.

[40] E. Erdogdu, "On the wind energy in Turkey," Renewable \& Sustainable Energy Reviews, vol. 13, pp. 361-371, 2009.

[41] C. Ilkılıç, H. Aydın, and R. Behçet, "The current status of wind energy in Turkey and in the world," Energy Policy, vol. 39, pp. 961-967, 2011.

[42] O. Ozgener and A. Hepbasli, "Current status and future directions of wind energy applications in Turkey," Energy Sources, vol. 24, no. 12, pp. 1117-1129, 2002.

[43] F. Evrendilek and C. Ertekin, "Assessing the potential of renewable energy sources in Turkey," Renewable Energy, vol. 28, no. 15, pp. 2303-2315, 2003.

[44] M. Ocak, Z. Ocak, S. Bilgen, S. Keleş, and K. Kaygusuz, "Energy utilization, environmental pollution and renewable energy sources in Turkey," Energy Conversion and Management, vol. 45, no. 6, pp. 845-864, 2004.

[45] I. Yüksel, "Global warming and renewable energy sources for sustainable development in Turkey," Renewable Energy, vol. 3, pp. 802-812, 2008.

[46] R. Oğulata, "Potential of renewable energies in Turkey," Journal of Energy Engineering, vol. 133, pp. 63-68, 2007.
[47] S. Keleş and S. Bilgen, "Renewable energy sources in Turkey for climate change mitigation and energy sustainability," Renewable \& Sustainable Energy Reviewsiews, vol. 16, pp. 5199-5206, 2012.

[48] M. Çapik, A. O. Yilmaz, and T. Çavuşoğlu, "Present situation and potential role of renewable energy in Turkey," Renewable Energy, vol. 46, pp. 1-13, 2012.

[49] I. Yuksel and K. Kaygusuz, "Renewable energy sources for clean and sustainable energy policies in Turkey," Renewable \& Sustainable Energy Reviews, vol. 15, pp. 4132-4144, 2011.

[50] S. Volkan and E. K. Ediger, "Renewable energy potential as an alternative to fossil fuels in Turkey, Energy Conversion \& Management, vol. 40, pp. 743-755, 1999.

[51] D. Kaya, "Renewable energy policies in Turkey," Renewable \& Sustainable Energy Reviewsiews, vol. 10, pp. 152-163, 2006.

[52] K. Kaygusuz and A. Sari, "Renewable energy potential and utilization in Turkey," Energy Conversion Management, vol. 44, pp. 459-478, 2003.

[53] A. Akpinar, M. I. Komurcu, M. Kankal, I. H. Ozolcer, and K. Kaygusuz, "Energy situation and renewables in Turkey and environmental effects of energy use," Renewable \& Sustainable Energy Reviews, vol. 12, pp. 2013-2039, 2007.

[54] M. Kenisarin, M. V. Karsli, and M. Caglar, "Wind power engineering in the world and perspectives of its development in Turkey," Renewable \& Sustainable Energy Reviews, vol. 10, pp. 341-369, 2006.

[55] Global cumulative installed wind capacity 1996-2010, http://www.gwec.net/.

[56] Wind Energy International 2011/2012 yearbook, http:// www.sonnenseite.com/.

[57] EÜAŞ Sector Report, "Electrical Energy Production Sector Report," Turkey, 2008.

[58] Energy Policies of IEA Countries, 2010, http://www.iea.org/.

[59] Electricity Generation \& Transmission Statistics of Turkey, 2010, http://www.teias.gov.tr/.

[60] Key World Energy Statistic, International Energy Agency; 2011.

[61] Global Wind Report-Annual market update, 2010, http:// www.gwec.net/.

[62] http://www.tureb.com.tr/.

[63] A report by the European Wind Energy Association, The economics of wind power, March 2009, http://www.windenergy-the-facts.org/. 


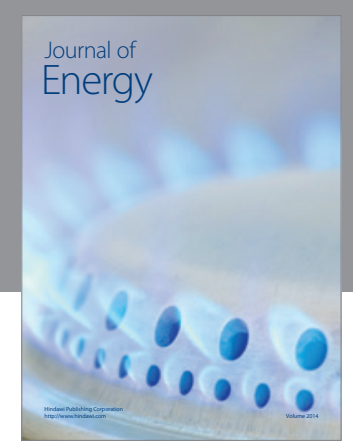

Journal of

Industrial Engineering
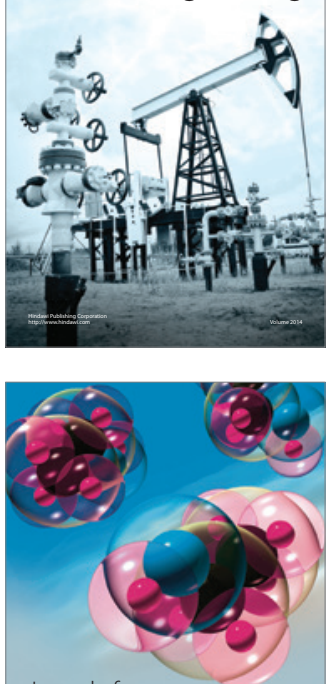

Fuels
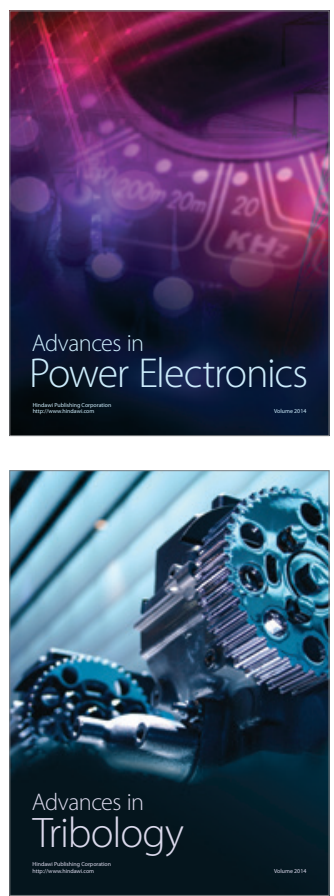

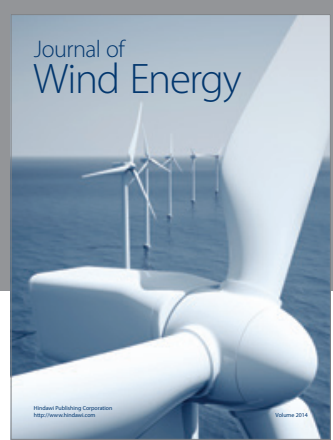

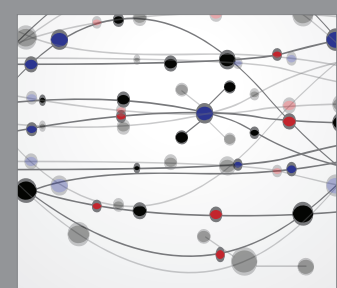

The Scientific World Journal

Submit your manuscripts at http://www.hindawi.com

Journal of

Structures
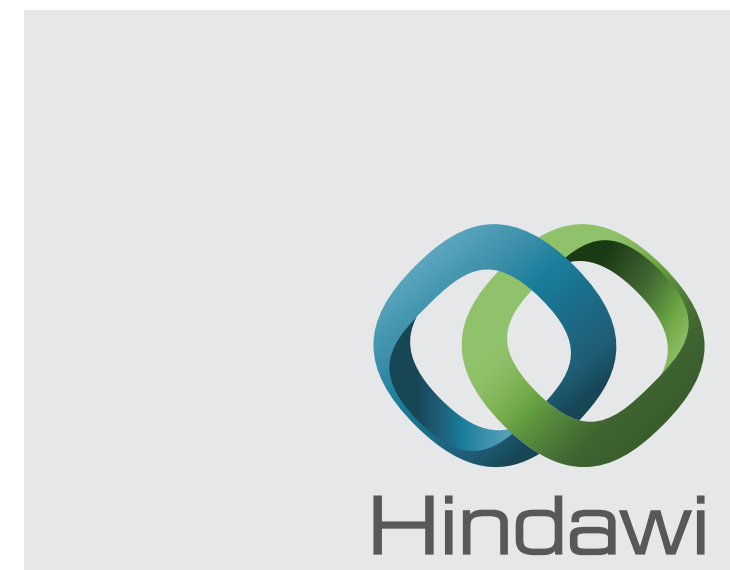

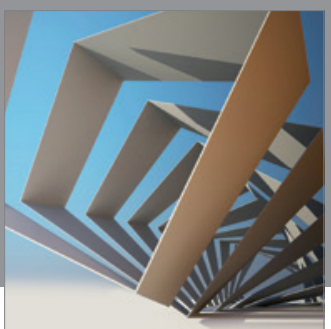

Rotating

Machinery
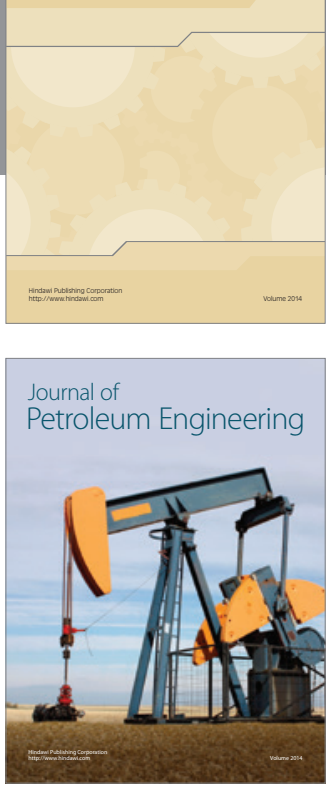

Journal of

Solar Energy
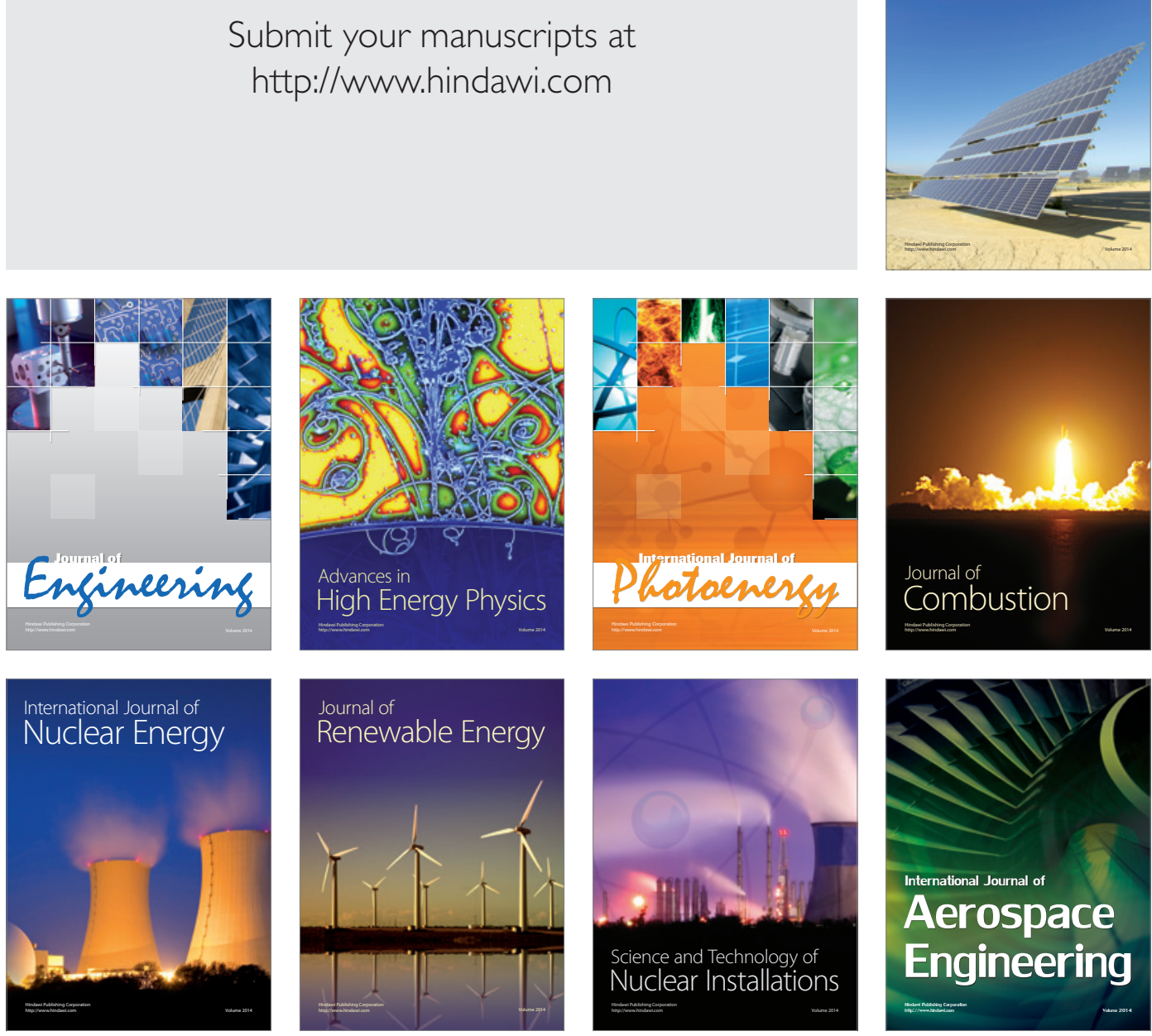